\title{
Host Factors Influences on Treatment Response in Chronic Hepatitis C Patients Treated with pegINF and Ribavirin in Albania
}

\author{
Anila Kristo ${ }^{1}$, Dr. Jovan Basho ${ }^{2}$, Nikollaq Leka ${ }^{3}$, Dr. Elizana Petrela ${ }^{4}$, Jonila Cela ${ }^{5}$ \\ ${ }^{1}$ Department of Morfology, University of Medicine (UMT), Tirana, Albania \\ ${ }^{2}$ Professor, Service of Gastro-Hepatology, UHC "Mother Tereza”, Tirana, Albania \\ ${ }^{3}$ Associate Professor, Department of Morphology, University of Medicine, Tirana \\ ${ }^{4}$ Professor, Service of Statistics, Faculty of Public Health, UHC "Mother Tereza", Tirana, Albania \\ ${ }^{5}$ University of Medical and Technical Science, Elbasan, Albania
}

\begin{abstract}
Introduction: The impact of viral factors like genotype, HCVRNA at baseline, or viral kinetics during treatment of chronic hepatitis $C$ patients is better defined recently. In contrary different results comes from studies about the impact of age, gender or BMI on treatment response in chronic hepatitis $\mathrm{C}(\mathrm{CHC})$ with standard scheme. Aim: To evaluate the predictive value of host factors (age, gender, BMI, biochemical and hematological profile) on treatment response in CHC patients in Albania. Patients and Methods: A total of 151patients, diagnosed with CHC in UHC "Mother Tereza" service of Gastro-Hepatology were included in this study. All the patients were treated with PegINF alfa-2a (180 $\mathrm{gg}$ s.c/week) and ribavirin 800-1200 mg/day (according to body weight and genotype). The duration of treatment varied from 24-48 to 72 weeks according to genotype and virological response. Patients were assessed for age, gender, BMI, TC (total cholesterol),TGC, Fast blood glucose (FBG), GGT, AST, ALT, WBC, PLT, HB and was evaluated their impact on treatment response in both $S V R$ and Non-SVR group. Data were analyzed statistically by Chi square test and $T$ test. $P<0.05$ is considered significant. Results: In general patients aged $<45$ years/old had a $S V R$ rates of $59.2 \%$ and those $\geq 45 y e a r s / o l d ~ 64 \%$ without significant differences between groups (Chi-square $=0.366, d f=1, p=0.545$ ). Female patients had a $S V R$ rate of $63.7 \%$ and males $59.7 \%$ (Chi-square $=0.255, d f=1, p=0.614)$ without significant differences between groups. The $S V R$ rates of females $<45$ years /old, females $\geq$ $45 \mathrm{ys} /$ old, males $<45 \mathrm{ys} /$ old and males $\geq 45 \mathrm{ys} /$ old were respectively $66.7 \%, 61.9 \%, 55 \%$, 66.7\% in all cases without significant differences between groups. Through binary logistic regression technique, is shown that there is a causal link, statistically significant between the non-SVR and BMI $\geq 27 \mathrm{~kg} / \mathrm{m} 2$; It can be said that patients with BMI $>/=27 \mathrm{~kg} / \mathrm{m} 2$, are 2.6 times more likely than patients with BMI <27kg / m2, not to achieve SVR. (OD:2.58, CI 95\%: 1.59-5.67). Significant statistical differences in baseline TC, GGT and PLT were found between SVR and non -SVR groups. Conclusions: BMI $\geq 27$, low level of TC, low level of PLT and high level of GGT at baseline are significant negative baseline predictors of SVR. Age and gender are not predictors of treatment response in CHC patients in Albania.
\end{abstract}

Keywords: hepatitis C, host factors, treatment, impact

\section{Introduction}

It is estimated that approximately 170 million individuals, i.e. $2.35 \%$ of the world population, are chronically infected with $\mathrm{HCV}$. Overall, HCV prevalence across Europe ranges between $0.4 \%$ and $3.5 \%$, with wide geographical variation and higher rates in the south and the east (2.3). The genotypes $(1,2,3,4,5,6$ \& 7) show differences with regard to their worldwide distribution, transmission and disease progression (4). Genotype 1 is the most prevalent genotype worldwide, with a higher proportion of subtype $1 \mathrm{~b}$ in Europe and $1 \mathrm{a}$ in the USA. In Western Europe, HCV prevalence ranges from $0.4 \%$ to $3 \%$ (5). According studies conducted by Institute of Public Health in Albania the prevalence of hepatitis $\mathrm{C}$ varied in the population from $0.9-1.3 \%(6,7)$. Genotipe $1 \mathrm{~b}$ is the most prevalent genotype in Albania nearly $65 \%-70 \%$, followed by genotype 2 and 3 nearly 25 $30 \%$ and genotype 4 only $1 \%$ (8). The objective of antiviral therapy is to obtain a sustained virologic response (SVR), defined as undetectable HCV RNA during treatment and 24 weeks after the end of treatment. In the last decade, treatment of $\mathrm{CHC}$ with pegINF $2 \mathrm{a}$ or $2 \mathrm{~b}$ combined with weight-based ribavirin (RBV) for 48 weeks (genotypes 1, 4, 5 and 6) or 24 weeks (genotypes 2 and 3 ), has been considered the standard of care (SOC) for HCV treatment. Treatment with pegIFN/RBV dual therapy is costly and is associated with side effects. Before initiating treatment, it is useful for patients and physicians to determine the likelihood of achieving a SVR, so that they can decide whether treatment benefits outweigh its costs and risks. The impact of viral factors in pegINF/RBV scheme is better defined. $\mathrm{HCV}$ genotype is one of the important baseline predictor for response. Genotype-1 infected patients achieve a SVR ranging from $41-52 \%$ after 48 weeks of peg-IFN plus RBV as opposed to $76-84 \%$ in genotypes 2 and 3 (9.10.11). Genotype 4 patients treated for 48 weeks showed response rates at an intermediate level compared to genotype 1 and genotypes 2 or 3 , with SVR rates between $65 \%$ and $72 \%$ (12.13). A low baseline viral load $(<600,000-800,000 \mathrm{IU} / \mathrm{ml}$ or less) is an independent predictor of SVR regardless to genotype in many studies (11.14.15) and patients with pretreatment high viral loads have lower SVR rates than patients with low viral loads. Once treatment has been initiated, monitoring of HCV RNA decline has become an increasingly important tool for the prediction of SVR $(14,16,17)$. In particular, rapid virological response (RVR) has been recognized as one of the most powerful predictors of SVR and, when assessed in combination with baseline viral load, can be used to identify patients for whom a shortened treatment course is appropriate. Regarded to host factors many studies confirm the impact of race on treatment (18.19.20.21) and the impact of IL28B gene SNPs which are 


\section{International Journal of Science and Research (IJSR) \\ ISSN (Online): 2319-7064 \\ Index Copernicus Value (2013): 6.14 | Impact Factor (2014): 5.611}

strongly associated with $\mathrm{HCV}$ clearance, whether spontaneous or treatment-related (22). In general it is believed that younger age, females and low BMI levels have better treatment results but contradictory results come from different studies. For these reason we conducted this study to establish and better define the impact of host factors in our patients with chronic hepatitis $\mathrm{C}$ and so better predict the treatment response.

\section{Aim}

To evaluate the predictive value of host factors (age, gender, BMI, biochemical and hematological profile at baseline) on treatment response in $\mathrm{CHC}$ patients in Albania.

\section{Patients and Methods}

A total of 151patients, diagnosed with $\mathrm{CHC}$ in UHC "Mother Tereza" service of Gastrohepatology were included in this study. The following were considered to be contraindications for treatment: current liver decompensation, immunosuppressive treatment within the last six months, associated liver diseases (especially autoimmune hepatitis) and other associated serious diseases such as systemic autoimmune disease, neoplasia, cardiac arrhythmias and ischemic vascular disease. All these patients were treated with PegINF alfa-2a (180 $\mu \mathrm{g}$ s.c/week) and Ribavirin 800-1200 mg/day (according to genotype and body weight). Patients with genotype land 4 were treated in general for 48 weeks and for genotypes 2 and 3, 24 weeks but the duration of treatment varied from 24-48 to 72 weeks according EASL recommendations depended also from the virological response during treatment. Success of treatment was considered HCVRNA negative during treatment and 24 weeks after the end of the treatment (SVR). HCVRNA negative were considered levels below $50 \mathrm{IU} / \mathrm{ml}$ of HCVRNA. Patients were assessed for age, gender, BMI, TC,TGC, Fast Glucose, GGT, AST, ALT, WBC, PLT, HB and was evaluated their impact on treatment response in both SVR and Non-SVR group. Data were analyzed statistically by Chi square test and T test. Values of $\mathrm{P}<0.05$ are considered statistically significant.

\section{Results}

The distribution of genotypes among 151 patients was: Genotype 1b (89pt) 59\%, 1a (2pt) 1.3\%; genotype 2 (48pt) $31.7 \%$; genotype 3 (9pt) $6 \%$; genotype 4 (3pt) $2 \%$. From all patients 93 achieved sustained virological response (SVR) so the SVR rate independently of genotype was $61.5 \%$. In the group with genotypes 1 and 4 the SVR rate was $43.6 \%$ while with genotypes 2 and 3 the SVR rate was $88 \%$ with significant difference between the groups $(\mathrm{p}<0.001)$. The median age \pm STD of patients enrolled in the study was $45.5 \pm 13.3$ years/old. From all patients 82 were males $(54.3 \%)$ and 69 females (45.7\%). In general patients aged $<$ 45 years/old had a SVR rates of $59.2 \%$ and those $\geq$ 45years/old $64 \%$ without significant differences between groups (Chi-square $=0.366, \mathrm{df}=1, \mathrm{p}=0.545$ ). Female patients had a SVR rate of $63.7 \%$ and males $59.7 \%$ (Chi-square $=0.255, \mathrm{df}=1, \mathrm{p}=0.614)$ without significant differences between groups (Table 1)
Table 1: The impact of age and gender on SVR

\begin{tabular}{|c|c|c|c|c|c|}
\hline \multirow{2}{*}{\multicolumn{2}{|c|}{ Variables }} & \multicolumn{2}{|c|}{ HCVRNA_post terapi } & \multirow[t]{2}{*}{ Total } & \multirow{2}{*}{$\begin{array}{l}P \\
\text { value }\end{array}$} \\
\hline & & Non-SVR & SRV & & \\
\hline \multirow[t]{4}{*}{ Gender } & \multirow[t]{2}{*}{$f$} & 25 & 44 & 69 & \multirow[t]{4}{*}{0.614} \\
\hline & & $43.1 \%$ & $47.3 \%$ & $45.7 \%$ & \\
\hline & \multirow[t]{2}{*}{$\mathrm{m}$} & 33 & 49 & 82 & \\
\hline & & $56.9 \%$ & $52.7 \%$ & $54.3 \%$ & \\
\hline \multirow[t]{4}{*}{ Age } & \multirow[t]{2}{*}{$>=45$ vjec } & 27 & 48 & 75 & \multirow[t]{4}{*}{0.545} \\
\hline & & $46.6 \%$ & $51.6 \%$ & $49.7 \%$ & \\
\hline & \multirow[t]{2}{*}{$<45$ vjec } & 31 & 45 & 76 & \\
\hline & & $53.4 \%$ & $48.4 \%$ & $50.3 \%$ & \\
\hline
\end{tabular}

*Chi square test

Through binary logistic regression technique, is shown that there is a causal link, statistically significant between the Non-SVR and BMI $\geq 27 \mathrm{~kg} / \mathrm{m} 2$; It can be said that patients with $\mathrm{BMI}>/=27 \mathrm{~kg} / \mathrm{m} 2$, are 2.6 times more likely than patients with BMI $<27 \mathrm{~kg} / \mathrm{m} 2$, not to achieve SVR (OD:2.58, CI 95\%: 1.59-5.67) (Table 2).

Table 2: The impact of BMI on SVR

\begin{tabular}{|c|c|c|c|c|}
\hline \multirow[t]{2}{*}{ BMI } & \multicolumn{2}{|c|}{ HCVRNA_pot terapi } & \multirow[t]{2}{*}{ OD } & \multirow[t]{2}{*}{ CI95\% } \\
\hline & $\begin{array}{c}\text { Non-SVR } \\
n=58(\%)\end{array}$ & $\begin{array}{c}\text { SRV } \\
n=93(\%)\end{array}$ & & \\
\hline$>=27 \mathrm{~kg} / \mathrm{m} 2$ & $40(69.0)$ & $43(46.2)$ & 2.58 & $1.59-5.67$ \\
\hline$<27 \mathrm{~kg} / \mathrm{m} 2$ & $18(31.0)$ & $50(53.8)$ & & erence \\
\hline
\end{tabular}

Significant statistical differences in baseline TC, GGT and PLT were found between Non-SVR and SVR groups (Table $3)$.

Table 3: The impact of biochemical and hematological profile on SVR

\begin{tabular}{|c|c|c|c|}
\hline $\begin{array}{c}\text { Baseline } \\
\text { parameters }\end{array}$ & Non-SVR group(58) & SVR group (93) & P value \\
\hline TC (mg/dl) & $151.71 \pm 31.55$ & $174.30 \pm 37.46$ & $\mathbf{0 . 0 0 5}$ \\
\hline $\begin{array}{c}\text { TGC } \\
\text { (mg/dl) }\end{array}$ & $115.14 \pm 68.21$ & $106.48 \pm 52.10$ & 0.5 \\
\hline $\begin{array}{c}\text { FBG } \\
\text { (mg/dl) }\end{array}$ & $107.32 \pm 41.72$ & $98.72 \pm 30.77$ & 0.5 \\
\hline GGT (UI/l) & $82.90 \pm 62.74$ & $56.56 \pm 57.55$ & $\mathbf{0 . 0 4}$ \\
\hline AST (UI/) & $62.8 / \mathrm{ml} \pm 33.57$ & $66.3 \pm 62.08$ & 0.35 \\
\hline ALT (UI/l) & $77,8 \pm 49.14$ & $114.4 \pm 136.4$ & 0.079 \\
\hline WBC/mm3 & $6143.33 \pm 1725.42$ & $6462.35 \pm 1718.63$ & 0.2 \\
\hline HB (g/dl) & $13.88 \pm 1.62$ & $13.79 \pm 1.60$ & 0.7 \\
\hline PLT /mm3 & $179145.37 \pm 64504.51$ & $219827.06 \pm 80966.55$ & $\mathbf{0 . 0 0 2}$ \\
\hline
\end{tabular}

\section{Discussion}

\section{a) Age}

Many study results confirm that patients age is a factor that is associated with responsiveness to Peg-IFN- $\alpha / \mathrm{RBV}$ therapy in chronic HCV infection. Generally, it is believed that younger individuals (usually $<40$ years of age) respond better to IFN- $\alpha$ treatment than older persons. In large prospective studies of (PEG) IFN and RBV combination therapy younger age correlated significantly with an SVR when assessed by univariate and multivariate analyses and patients younger than 40-45 years showed the best response rates $[9,10,11,23]$. The explanation is that older $\mathrm{HCV}$ patients are likely to have more advanced liver disease, such as fibrosis and cirrhosis (also predictors of poor virological 


\section{International Journal of Science and Research (IJSR) \\ ISSN (Online): 2319-7064 \\ Index Copernicus Value (2013): 6.14 | Impact Factor (2014): 5.611}

responses) and also mpairments in cellular, humoral, and innate immunity in the elderly may be another important factor that is responsible for decreasing successful responses to IFN- $\alpha$ treatment in older patients. In recent years various studies have been published that have shown that the elderly age is not a negative predictive factor for virological response to therapy with pegylated interferon- $\alpha$ and ribavirin in chronic hepatitis $\mathrm{C}$ virus patients, so a study conducted by Frei P. et al. (24) in matched pair analysis, SVR was not different in young and elderly patients (54.2 and 55.9\% respectively; $\mathrm{P}=0.795$ in binominal test). This fact was found also in our study which showed that in general patients aged $<45$ years/old had a SVR rates of $59.2 \%$ and those $\geq 45$ years/old $64 \%$ without significant differences between groups (Chi-square $=0.366, \mathrm{df}=1, \mathrm{p}=0.545)$ (Table $1)$.

When baseline and on treatment characteristics in both groups where compared resulted that although age $<45$ years/old had more positive predictive factors in baseline: statistically higher number of patients with BMI $<27$, lower fibrotic scale at baseline (assessed by FIB 4 test), and higher number of PLT at baseline, this group of age had a higher prevalence of genotype 1 and 4 which predicted a comparable treatment response between this group and the group with age $\geq 45$ years/ old (Table 4 ).

Table 4: Baseline and on treatment data in patients $<45$ years/old and $\geq 45$ years old

\begin{tabular}{|c|c|c|c|}
\hline $\begin{array}{c}\text { Patients baseline and on } \\
\text { treatment data }\end{array}$ & Age $\geq 45$ years/old & Age $<45$ years/ old & P value \\
\hline Gender (Male) & $33(44.0)$ & $49(64.5)$ & $\mathbf{0 . 0 1 2}$ \\
\hline BMI < 27 kg/m $\mathbf{2}^{2}$ & $27(36.0)$ & $41(53.9)$ & $\mathbf{0 . 0 2 7}$ \\
\hline GGT & $79.97 \pm 65.34$ & $57.55 \pm 52.28$ & 0.081 \\
\hline TC & $171.28 \pm 37.70$ & $160.93 \pm 35.74$ & 0.191 \\
\hline PLT & $184801.45 \pm 74175.94$ & $222969.29 \pm 76241.64$ & 0.003 \\
\hline HCVRNA & $2.77 \times 10^{6} \pm 8.4 \times 10^{6}$ & $3.1 \times 10^{6} \pm 6.38 \times 10^{6}$ & 0.787 \\
\hline HCVRNA baseline $<400 ~ 000$ & $28(37.3)$ & $30(39.5)$ & $\mathbf{0 . 0 3 8}$ \\
\hline Genotype 1 and 4 & $40(53.3)$ & $53(69.7)$ & 2.287 \\
\hline RVR & $21(53.8 \%)$ & $19(42.2 \%)$ & $<\mathbf{0 . 0 0 1}$ \\
\hline FIB 4 test & $2.64 \pm 2.26$ & $1.20 \pm 0.92$ & \\
\hline
\end{tabular}

\section{b) Gender}

A large analysis $(n=1744)$ of two trials involving standard IFN plus RBV therapy showed a significant positive correlation between female gender and SVR $(\mathrm{p}<0.004)$ (24). No such difference has been confirmed in studies involving Peg-IFN plus RBV $(10,11,25,26,27)$. In accordance to these studies female patients had a higher SVR rate $(63.7 \%)$ than males $(59.7 \%)$ (Chi-square $=0.255$, $\mathrm{df}=1, \mathrm{p}=0.614$ ) but without significant differences between groups. When the groups male / female were analyzed it was found that although women had significant positive predictive factors like higher RVR rates, lower GGT levels at baseline compared to males they had higher percentage of age $\geq 45$ year/olds compared to males (Table 5). The unfavorable effect of treatment in women $>45$ years is apparently related to the reduced amount of estrogen after this age. It has been proposed that estrogen may suppress hepatic fibrosis through an effect that depends on its hepatic tissue receptors, and improve the antiviral therapy, in females $<45$ years/old (28).

Table 5: Baseline and on treatment data in males/females

\begin{tabular}{|c|c|c|c|}
\hline Baseline and on treatment data & Female group & Male group & P value \\
\hline Age $<\mathbf{4 5}$ vjec & $27(39.1)$ & $49(59.8)$ & $\mathbf{0 . 0 1 2}$ \\
\hline BMI <27 kg/m & $25(50.7)$ & $33(40.2)$ & 0.197 \\
\hline GGT & $49.24 \pm 47.67$ & $81.54 \pm 66.02$ & 0.013 \\
\hline TC & $168.39 \pm 34.89$ & $164.47 \pm 39.00$ & 0.733 \\
\hline PLT & $206492.06 \pm 85755.63$ & $201975.66 \pm 70160.90$ & 0.948 \\
\hline HCVRNA in baseline & $2.93 \times 10^{6} \pm 8.94 \times 10^{6}$ & $3.02 \times 10^{6} \pm 5.92 \times 10^{6}$ & 0.866 \\
\hline HCVRNA < 400 000 Ui/ml & $26(37.7)$ & $32(39.0)$ & 0.240 \\
\hline Genotype 1 and 4 & $39(56.5)$ & $54(65.9)$ & $\mathbf{0 . 0 0 9}$ \\
\hline RVR & $25(62.5 \%)$ & $15(34.1 \%)$ & 0.206 \\
\hline FIB 4 test & $2.14 \pm 2.28$ & $1.82 \pm 1.42$ & \\
\hline
\end{tabular}

The SVR rates of females $<45$ years /old, females $\geq 45$ ys/old, males $<45$ ys/old and males $\geq 45$ ys/old were respectively $66.7 \%, 61.9 \%, 55 \%, 66.7 \%$. When we assessed gender in relation to age resulted that females $<45$ ys/old had higher SVR rates than males of the same age $(66.7 \%$ vs $55 \%$ ) and older males $>45$ years/old had higher SVR rates than younger males $(66.7 \%$ vs $55 \%)$ but in all cases without significant differences between groups. Similar results have been found also from Jian $-\mathrm{Wu}$ et al. which in their study concluded that in the group of patients aged $<40$ years, the SVR rate of females was higher than that of males; in the group of patients aged 40-50 years, females and males shared similar SVR rates; in the group of patients aged 5160 years, the SVR rate of females was lower than that of males (29).

\section{Volume 4 Issue 11, November 2015}




\section{International Journal of Science and Research (IJSR) \\ ISSN (Online): 2319-7064 \\ Index Copernicus Value (2013): 6.14 | Impact Factor (2014): 5.611}

c) BMI, overweight, obesity

According a study conducted by $\mathrm{K}-\mathrm{Q}$. $\mathrm{Hu}$ et al. being overweight/obese (BMI $>25 \mathrm{~kg} / \mathrm{m} 2$ ) serves as an independent risk factor for hepatic steatosis in U.S. patients with CHC. Steatosis accelerates activity and progression of $\mathrm{CHC}$, and was independently associated with stage III/IV hepatic fibrosis in these patients (30). Obesity has been reported to be a risk factor of non-response independent of the HCV genotype and the presence of cirrhosis. Obese patients defined as BMI $>30$ have approximately a $80 \%$ lower chance of achieving SVR compared with non-obese patients (31). As mentioned above obesity and high BMI induces: (1) the metabolic syndrome leading to insulin resistance, hepatic steatosis, and higher baseline viral load, (2) altered cytokine signaling manifested by elevated levels of leptin, adiponectin, and resistin (3) reduced bioavailability of interferon-a (31.32). (4)Certain peg-IFN also may be preferentially absorbed through blood capillaries or the lymphatic circulation. Since obese people are known to have a poor lymphatic circulation (33), this could result in suboptimal serum levels of peg-IFN and a reduced response to antivirals. (5)Obesity may also affect the antiviral response modulating the interferon (IFN) signaling pathway. Normally, interferon alpha (IFN-'a)activated cellular signaling is negatively regulated by inhibitory factors such as the suppressor cytokine signaling (SOCS) family. Obese subjects infected with HCV genotype 1 had increased hepatic expression of SOCS-3, a factor that has been shown to inhibit IFN-a signaling. This relationship between obesity and increased SOCS-3 expression remained significant after correction for other factors associated with non-response to treatment. (34). In patients with genotype 3 infection, fatty liver can occur in the absence of obesity and insulin resistance $(35,36)$ suggesting a viral etiology with mechanisms related to how core protein affects lipid oxidation and very low-density lipoprotein assembly (37) while in non genotype 3 infections, steatosis is most common in patients who are obese and insulin resistant (36). However, these results about impact of BMI on SVR were not confirmed in other large studies with $\mathrm{PEG} / \mathrm{RBV}$ combination therapy in $\mathrm{HCV}$ genotypes 1- 3-infected patients in which multilogistic regression analyses including BMI and body weight were conducted (38.39). In our study resulted that median level of BMI was lower in SVR group than Non-SVR $25.1 \pm 4.5$ vs $26.5 \pm 3.7 \mathrm{~kg} / \mathrm{m} 2$ but without statistical differences. Meanwhile when we compared two groups with a cut-off value of 27 through binary logistic regression technique, resulted that there was a causal link, statistically significant between non-SVR and BMI $\geq 27 \mathrm{~kg}$ / $\mathrm{m} 2$; It can be said that patients with $\mathrm{BMI}>/=27 \mathrm{~kg} / \mathrm{m} 2$, are 2.6 times more likely than patients with BMI $<27 \mathrm{~kg} /$ $\mathrm{m} 2$, not to achieve SVR. (OD: 2.58, CI 95\%: 1.59-5.67).

\section{d) Biochemical profile in baseline}

Many studies have concluded that the level of ALT in baseline does not predict SVR in multilogistic regression $(10,40)$. We confirmed this result in our study. The median \pm STD of ALT in SVR group was $114.4 \pm 136.4$ and in NonSVR $77.8 \pm 49.14$ without statistical differences between the groups $(\mathrm{p}=0.079)$. On the other hand in some studies low pretreatment serum of GGT levels significantly and independently are associated with SVR in multivariate regression analyses due to the relationship between serum GGT levels and hepatic steatosis, advanced fibrosis, and insulin resistance $(41,42)$. GGT participates in the transfer of amino acids across cell membrane, and also in glutathione (an anti-oxidant) metabolism. The induction of GGT is an adaptive response against oxidative stress elicited by lipid peroxidation in the presence of hepatic steatosis (43). In our study the group with Non- SVR had higher levels of GGT than SVR and these differences were significant $(82.9 \pm 62.7$ vs $56.56 \pm 57.55 ; \mathrm{p}=0.04$ )

Several studies indicate that high pretreatment low density lipoprotein cholesterol (LDLc) and TC (Total cholesterol) levels are associated with higher rates of SVR in multivariable analyses $(44,45,46,47)$. In patients with chronic hepatitis $\mathrm{C}$, serum lipid levels have been reported to be correlated with specific cytokines that may have antiviral activity, including tumor necrosis factor-alpha and interleukin-6 (48). This hyperlipidemia induced increase in cytokine levels may have a favorable and potentially additive effect on antiviral treatment in patients with chronic hepatitis C. Another proposed mechanism may be related to a possible regulatory effect of cholesterol in $\mathrm{HCV}$ binding to cell surface receptors, which in turn may be relevant to viral clearance (49). The LDL receptor, a membrane glycoprotein, has been shown to be involved in HCV entry into hepatocytes, and data suggest that HCV RNA levels correlate with LDL receptor expression $(50,51)$. Elevated serum concentrations of LDL may decrease the number of LDL receptors located on hepatocytes. A cut-off value of total cholesterol of $177 \mathrm{mg} / \mathrm{dL}$ was proposed in a study made by Naota Taura et al. (52). This cut-off value of total cholesterol level was lower than other previous studies $(46,47)$. In our study we propose a cut-off value of cholesterol of $150 \mathrm{mg} / \mathrm{dl}$. 


\section{International Journal of Science and Research (IJSR) \\ ISSN (Online): 2319-7064}

Index Copernicus Value (2013): 6.14 | Impact Factor (2014): 5.611

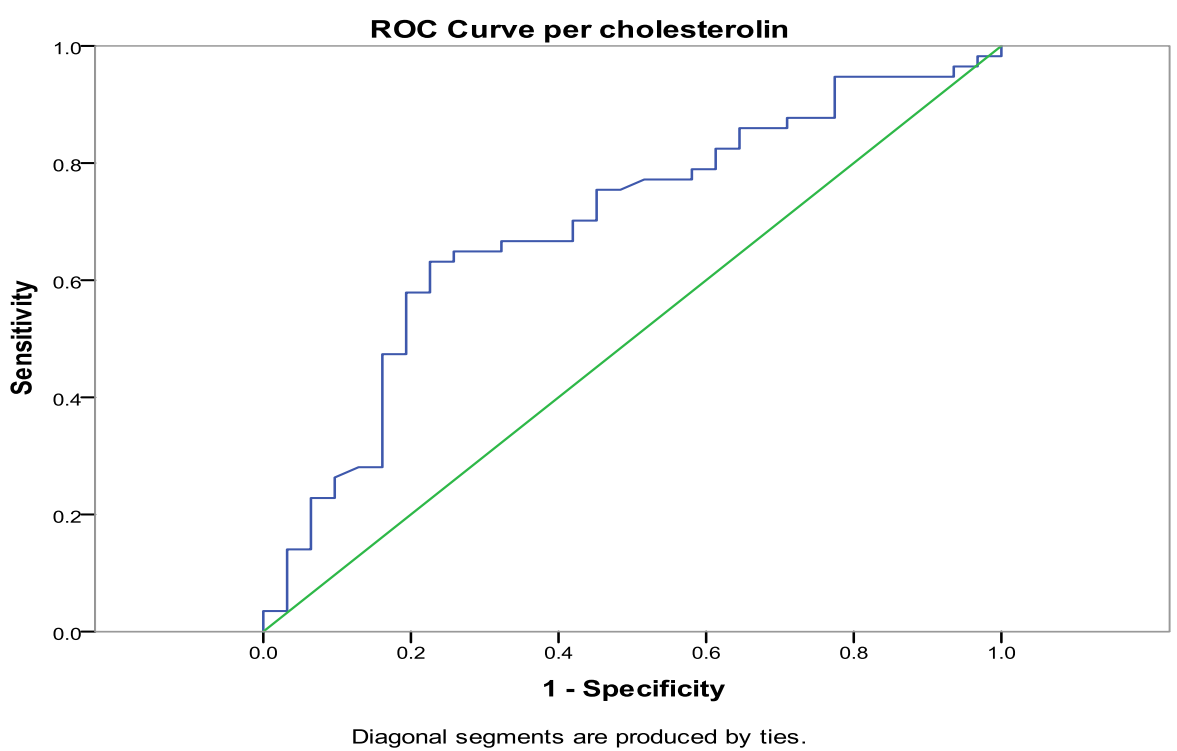

Graph 1: ROC curve for Cholesterol

(Area under the curve is 0.693; $p=0.003$; Cut-off value is cholesterol $=150 \mathrm{mg} / \mathrm{dl}$ )

\section{e) Hematological profile at baseline}

The number of platelets in baseline may predict response to antiviral therapy. Thrombocytopenia occasionally accompanies advanced chronic liver diseases (53), therefore should have a lower response rate to therapy and also is related to antiviral therapy as a serious side effect which may lead to dose modifications or treatment interruption (54, $55,56)$. In our study we confirmed this result and also proposed a cut-off value of PLT of $173000 / \mathrm{mm} 3$. Regardless to $\mathrm{WBC}$ and $\mathrm{HB}$ at baseline there were no significant differences between the two groups.

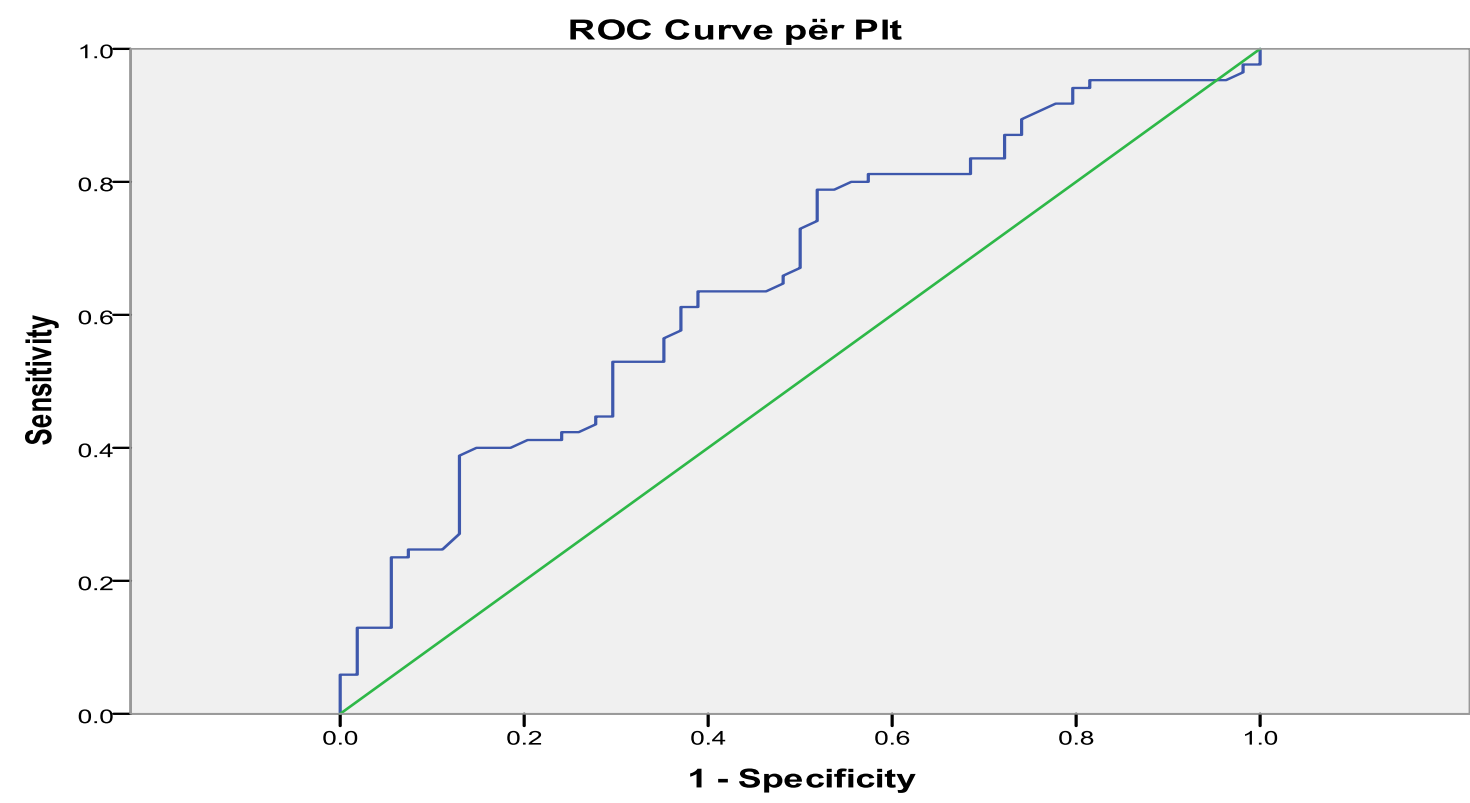

Diagonal segments are produced by ties.

Graph 1: ROC curve for PLT

(Area under the curve is $0.656 ; \mathrm{p}=0.002$; Cut-off value is $\mathrm{PLT}=173000 / \mathrm{mm}^{3}$ )

\section{Conclusion}

Higher BMI levels at baseline ( $\geq 27 \mathrm{~kg} / \mathrm{m} 2$ ), lower level of TC, lower level of PLT and higher level of GGT are significant negative baseline predictors of SVR. Age and gender are not significant predictors of treatment response in $\mathrm{CHC}$ patients in Albania although younger female patients $<$ $45 \mathrm{ys} /$ old tend to respond better than males of the same age and older males have greater chances of achieving SVR than younger males related this to the greater percentage of genotype $1 \mathrm{~b}$ in younger age in Albania.

\section{References}

[1] Lavanchy D. Evolving epidemiology of hepatitis C virus. Clin Microbiol Infect 2011;17:107-115

[2] Cornberg M, Razavi HA, Alberti A, Bernasconi E, Buti $\mathrm{M}$, Cooper $\mathrm{C}$, et al. A systematic review of hepatitis $\mathrm{C}$ 


\section{International Journal of Science and Research (IJSR) \\ ISSN (Online): 2319-7064}

Index Copernicus Value (2013): 6.14 | Impact Factor (2014): 5.611

virus epidemiology in Europe, Canada and Israel. Liver Int 2011;31:30-60.

[3] 3.Blachier M, Leleu H, Peck-Radosavljevic M, Valla DC, Roudot-Thoraval F. The burden of liver disease in Europe, a review of available epidemiological data. Geneva: European Association for the Study of the, Liver; 2013.

[4] Smith 2014 Smith DB, Bukh J, Kuiken C, et al. Expanded classification of hepatitis $\mathrm{C}$ virus into 7 genotypes and 67 subtypes

[5] Lavanchy D. The global burden of hepatitis C. Liver Int 2009;29:74-81

[6] Basho M, Qyra SH, Basho J, Bino S, Kakarriqi E. The seroprevalence of viral hepatitis in Albanian recruits The $10^{\text {th }}$ Balkan Journal of Clinic Laboratory Federation. 2002; 135-136

[7] Basho M,Qyra Sh,Bino S,Marku E,Basho Gj,Kureta E et al. Seroprevalence of viral hepatitis B,C and D in Healthy adults contigent of Albanian population. International Public Health Conference. Abstract book, Tirana, 24 April 2014; 135

[8] Kristo A., Çela J., Dino E., Rapi E., Lamja E., Aliu Q., Leka N., Basho J. Predictive factors for achieving sustained virological response among patients with chronic Hepatitis $\mathrm{C}$ treated with pegasys interferon and ribavirine. Albanian Medical Journal 2013;4)

[9] Shiffman, M.L., Suter, F., Bacon, B.R., Nelson, D., Harley, H., Sola, R. et al. (2007a) Peginterferon alfa-2a and ribavirin for 16 or 24 weeks in HCV genotype 2 or 3. N Engl J Med 357: 124 134

[10]Fried, M.W., Shiffman, M.L., Reddy, K.R., Smith, C., Marinos, G., Gonc,ales, Jr F.L. et al. (2002) Peginterferon alfa-2a plus ribavirin for chronic hepatitis C virus infection. N Engl J Med 347: 975982.

[11] Manns, M.P., McHutchison, J.G., Gordon, S.C., Rustgi, V.K., Shiffman, M., Reindollar, R. et al. (2001) Peginterferon alfa-2b plus ribavirin compared with interferon alfa-2b plus ribavirin for initial treatment of chronic hepatitis $\mathrm{C}$ : a randomized trial. Lancet 358: 958_965.

[12] Alfaleh, F.Z., Hadad, Q., Khuroo, M.S., Aljumah, A., Algamedi, A., Alashgar, H. et al. (2004) Peginterferon alpha-2b plus ribavirin compared with interferon alpha$2 \mathrm{~b}$ plus ribavirin for initial treatment of chronic hepatitis $\mathrm{C}$ in Saudi patients commonly infected with genotype 4 . Liver Int 24: 568574.

[13] Khuroo, M.S., Khuroo, M.S. and Dahab, S.T. (2004) Meta-analysis: a randomized trial of peginterferon plus ribavirin for the initial treatment of chronic hepatitis $\mathrm{C}$ genotype 4. Aliment Pharmacol Ther 20: 931_938.

[14]ZeuzemS,ButiM, Ferenci

P,Sperl J,HorsmansY,Cianciara J, et al. Efficacy of 24 weeks treatment with peginterferon alfa-2b plus ribavirin in patientswith chronic hepatitisCinfectedwith genotype 1 and low pretreatment viremia. J Hepatol 2006;44:97103

[15]Berg, T., Sarrazin, C., Herrmann, E., Hinrichsen, H., Gerlach, T., Zachoval, R. et al. (2003) Prediction of treatment outcome in patients with chronic hepatitis $\mathrm{C}$ : significance of baseline parameters and viral dynamics during therapy. Hepatology 37: 600_609.

[16] Fried MW, Hadziyannis SJ, Shiffman M, Messinger D, Zeuzem S. Rapid viral response is a more important predictor of sustained virological response (SVR) than genotype in patients with chronic hepatitis $\mathrm{c}$ virus infection. J Hepatol 2008;48 (Suppl. 2):5A.

[17] Jensen DM, Morgan TR, Marcellin P, Pockros PJ, Reddy KR, Hadziyannis SJ, et al. Early identification of $\mathrm{HCV}$ genotype 1 patients responding to 24 weeks peginterferon alpha-2a $(40 \mathrm{kd}) /$ ribavirin therapy. Hepatology 2006;43:954-960.

[18] McHutchison JG, Poynard T, Pianko S, Gordon SC, Reid AE, Dienstag J, et al. The impact of interferon plus ribavirin on response to therapy in black patients with chronic hepatitis C. The International Hepatitis Interventional Therapy Group. Gastroenterology 2000;119:1317-1323.

[19] Brau N, Bini EJ, Currie S, Shen H, Schmidt WN, King $\mathrm{PD}$, et al. Black patients with chronic hepatitis $\mathrm{C}$ have a lower sustained viral response rate than non-Blacks with genotype 1 , but the same with genotypes $2 / 3$, and this is not explained by more frequent dose reductions of interferon and ribavirin. J Viral Hepat 2006;13:242249.

[20] Rodriguez-Torres M, Jeffers LJ, Sheikh MY, Rossaro L, Ankoma-Sey V, Hamzeh FM, et al. Virologic responses to Pegifn alpha-2a/ribavirin in treatment-Naive Latino vs non- Latino Caucasians infected with HCV genotype 1: the Latino study. Gastroenterology 2008;134 (Suppl. 1):755A

[21] Missiha S, Heathcote J, Arenovich T, Khan K. Impact of asian race on response to combination therapy with peginterferon alfa- $2 \mathrm{a}$ and ribavirin in chronic hepatitis C. Am J Gastroenterol 2007.

[22] Christian M. Lange, Stefan Zeuzem. IL28B single nucleotide polymorphisms in the treatment of hepatitis C. Journal of Hepatology 2011 vol. 55 j 692-701

[23] Poynard T, McHutchison J, Goodman Z, Ling MH, Albrecht J Is an , a la carte" combination interferon alfa-2b plus ribavirin regimen possible for the first line treatment in patients withchronic hepatitis C? The ALGOVIRC Project Group. Hepatology 2000;31:211218.

[24]Frei P, Leucht AK, Held U, Kofmehl R, Manser CN, Schmitt J et al; Swiss Hepatitis C Cohort Study Group. Liver Int. 2014 Apr;34(4):551-7. doi: 10.1111/liv.12279. Epub 2013 Aug 29.

[25] Hadziyannis SJ, Sette H Jr, Morgan TR, Balan V, Diago $\mathrm{M}$, Marcellin $\mathrm{P}$, et al. Peginterferon alfa-2a and ribavirin combination therapy in chronic hepatitis $\mathrm{C}$ : randomized study of treatment duration and ribavirin dose. Ann Intern Med 2004; 140:346-355.

[26] Almeida PR, de Mattos AA, Amaral KM, Feltrin AA, Zamin $\mathrm{P}$, Tovo $\mathrm{CV}$, et al. Treatment of hepatitis $\mathrm{C}$ with peginterferon and ribavirin in a public health program. Hepatogastroenterol 2009; 56:223-226.

[27] McHutchison JG, Lawitz EJ, Shiffman ML, Muir AJ, Galler GW, McCone J, et al. Peginterferon alfa-2b or alfa-2a with ribavirin for treatment of hepatitis $\mathrm{C}$ infection. N Engl J Med 2009; 361:580-593.public health program. Hepatogastroenterol 2009; 56:223-226

[28] Codes L, Asselah T, Cazals-Hatem D, Tubach F, Vidaud D, Parana' R, et al. Liverfibrosis in women with chronic hepatitis $\mathrm{C}$ : evidence for the negative role of the menopause and steatosis and the potential benefit of hormone replacement therapy. Gut 2007;56:390-5. 


\section{International Journal of Science and Research (IJSR) \\ ISSN (Online): 2319-7064 \\ Index Copernicus Value (2013): 6.14 | Impact Factor (2014): 5.611}

[29] Jian-Wu Yu, Li-Jie Sun', Yong-Hua Zhao, Peng Kang, Bing-Zhu Yan .Impact of sex on virologic response rates in genotype 1 chronic hepatitis $\mathrm{C}$ patients with peginterferon alpha-2a and ribavirin treatment. International Journal of Infectious Diseases Volume 15, Issue 11, November 2011, Pages e740-e746.

[30] Ke-Qin $\mathrm{Hu}$ et al. Overweight and obesity, hepatic steatosis, and progression of chronic hepatitis $\mathrm{C}$ : a retrospective study on a large cohort of patients in the United States; Journal of Hepatology 40 (2004) 147154

[31] Bressler BL, Guindi M, Tomlinson G, Heathcote J. High body mass index is an independent risk factor for nonresponse to antiviral treatment in chronic hepatitis C. Hepatology 2003; 38: 639-44

[32] Vendrell J, Broch M, Vilarrasa N, Molina A, Gomez JM, et al. (2004) Resistin, adiponectin, ghrelin, leptin, and proinflammatory cytokines: relationships in obesity. Obes Res 12: 962-971.

[33] Lam NP, Pitrak D, Speralakis R, Lau AH, Wiley TE, et al. (1997) Effect of obesity on pharmacokinetics and biologic effect of interferon-alpha in hepatitis C. Dig Dis Sci 42: 178-185.

[34] Walsh MJ, Jonsson JR, Richardson MM, et al. Nonresponse to antiviral therapy is associated with obesity and increased hepatic expression of suppressor of cytokine signalling 3 (SOCS-3) in patients with chronic hepatitis C, viral genotype 1. Gut 2006; 55: 529-35.

[35] Monto A, Alonzo J, Watson JJ, et al. Steatosis in chronic hepatitis $\mathrm{C}$ : relative contributions of obesity, diabetes mellitus, and alcohol. Hepatology 2002;36:729-736.

[36] Adinolfi LE, Gambardella M, Andreana A, Tripodi MF, Utili R, Ruggiero G. Steatosis accelerates the progression of liver damage of chronic hepatitis $\mathrm{C}$ patients and correlates with specific HCV genotype and visceral obesity. HEPATOLOGY 2001;33:1358-1364

[37] Barba G, Harper F, Harada T, et al. Hepatitis C virus core protein shows a cytoplasmic localization and associates to cellular lipid storage droplets. Proc Natl Acad Sci U S A 1997;94:1200- 1205.

[38] Jacobson IM, Brown Jr RS, Freilich B, Afdhal N, Kwo PY, Santoro J, et al. Peginterferon alfa-2b and weightbased or flatdose ribavirin in chronic hepatitis C patients: a randomized trial. Hepatology 2007;46:971981.

[39]Zeuzem S, Hultcrantz R, Bourliere M, Goeser T, Marcellin P, Sanchez-Tapias J, et al. Peginterferon alfa$2 b$ plus ribavirin for treatment of chronic hepatitis $\mathrm{C}$ in previously untreated patients infected with $\mathrm{HCV}$ genotypes 2 or 3. J Hepatol 2004;40:993-999

[40]Berg T, von Wagner M, Nasser S, Sarrazin C, Heintges $\mathrm{T}$, Gerlach T, et al. Extended treatment duration for hepatitis $C$ virus type 1 : comparing 48 versus 72 weeks of peginterferon-alfa- $2 \mathrm{a}$ plus ribavirin. Gastroenterology 2006;130:1086-1097

[41] Hwang SJ, Luo JC, Chu CW, Lai CR, Lu CL, Tsay SH, et al. Hepatic steatosis in chronic hepatitis $\mathrm{C}$ virus infection: prevalence and clinical correlation. $\mathrm{J}$ Gastroenterol Hepatol 2001;16:190-195.

[42] Silva IS, Ferraz ML, Perez RM, Lanzoni VP, Figueiredo VM, Silva AE. Role of gamma-glutamyl transferase activity in patients with chronic hepatitis $C$ virus infection. J Gastroenterol Hepatol 2004;19:314318

[43] Fierbinteanu-braticevici C, Mohora M, Cretoiu D et al. Role of oxidative stress in the pathogenesis of chronic hepatitis C (CHC). Roman. J. Morphol. Embryol. 2009; 50: 407-12.

[44] Hamamoto S, Uchida Y, Wada T, Moritani M, Sato S, Hamamoto $\mathrm{N}$, Ishihara $\mathrm{S}$, et al. Changes in serum lipid concentrations in patients with chronic hepatitis $\mathrm{C}$ virus positive hepatitis responsive or non-responsive to interferon therapy. J Gastroenterol Hepatol. 2005; 20:204-208. [PubMed: 15683422]

[45] Akuta N, Suzuki F, Kawamura Y, Yatsuji H, Sezaki H, Suzuki Y, Hosaka T, et al. Predictive factors of early and sustained responses to peginterferon plus ribavirin combination therapy in Japanese patients infected with hepatitis $\mathrm{C}$ virus genotype 1b: Amino acid substitutions in the core region and low-density lipoprotein cholesterol levels. J Hepatol. 2007; 46:403-410. [PubMed: 17126448]

[46] Economou M, Milionis H, Filis S, Baltayiannis G, Christou L, Elisaf M, Tsianos E. Baseline cholesterol is associated with the response to antiviral therapy in chronic hepatitis C. J Gastroenterol Hepatol. 2007

[47] Gopal K, Johnson TC, Gopal S, Walfish A, Bang CT, Suwandhi P, Pena-Sahdala HN, et al. Correlation between beta-lipoprotein levels and outcome of hepatitis C treatment. Hepatology. 2006; 44:335-340. [PubMed: 16871569]

[48] C. Fabris, E. Federico, G. Soardo, E. Falleti, and M. Pirisi, "Blood lipids of patients with chronic hepatitis: differences related to viral etiology," Clinica Chimica Acta, vol. 261, no. 2, pp. 159-165, 1997.

[49] M. Monazahian, I. Bohme, S. Bonk et al., "Low density lipo- " protein receptor as a candidate receptor for hepatitis C virus," Journal of Medical Virology, vol. 57, no. 3, pp. 223-229, 1999.

[50] J. M. Petit, A. Minello, L. Duvillard et al., "Cell surface expression of LDL receptor in chronic hepatitis C: correlation with viral load," American Journal of Physiology, vol. 293, no. 1, pp. E416-E420, 2007.

[51] S. Molina, V. Castet, C. Fournier-Wirth et al., "The lowdensity lipoprotein receptor plays a role in the infection of primary human hepatocytes by hepatitis $\mathrm{C}$ virus," Journal of Hepatology, vol. 46, no. 3, pp. 411419, 2007.

[52] Naota Taura, Tatsuki Ichikawa, Hisamitsu Miyaaki, et al., "Baseline Serum Cholesterol Is Associated with a Response to Pegylated Interferon Alfa-2b and Ribavirin Therapy for Chronic Hepatitis C Genotype 2,"Gastroenterology Research and Practice, vol. 2012, Article ID 317580, 7 pages, 2012. doi: $10.1155 / 2012 / 31758$

[53] Tejima K, Masuzaki R, Ikeda H, Yoshida H, Tateishi R, Sugioka $\mathrm{Y}$ et al. Thrombocytopenia is more severe in patients with advanced chronic hepatitis $\mathrm{C}$ than $\mathrm{B}$ with the same grade of liver stiffness and splenomegaly. J Gastroenterol 2010; 45: 876-884

[54] Tatsuo Kanda et al.Platelet count and sustained virological response in hepatitis $\mathrm{C}$ treatment World J Hepatol 2013 April 27; 5(4): 182-188 ISSN 1948-5182

\section{Volume 4 Issue 11, November 2015}




\section{International Journal of Science and Research (IJSR) \\ ISSN (Online): 2319-7064}

Index Copernicus Value (2013): 6.14 | Impact Factor (2014): 5.611

[55] Kauf TL, Nelson DR, Schelfhout J, Delaney JA, Wang $\mathrm{PF}$. Trends in the prevalence of thrombocytopenia among individuals infected with hepatitis $\mathrm{C}$ virus in the United States, 1999-2008. BMC Res Notes 2012; 5: 142

[56] Giannini EG, Marenco S, Fazio V, Pieri G, Savarino V, Picciotto A. Peripheral blood cytopaenia limiting initiation of treatment in chronic hepatitis $\mathrm{C}$ patients otherwise eligible for antiviral therapy. Liver Int 2012; 32: 1113-1119 